\title{
THE COAL RESOURCES OF THE PHILIPPINE ISLANDS.
}

\author{
W ARREN D. SMith. ${ }^{1}$
}

\section{CONTENTS.}

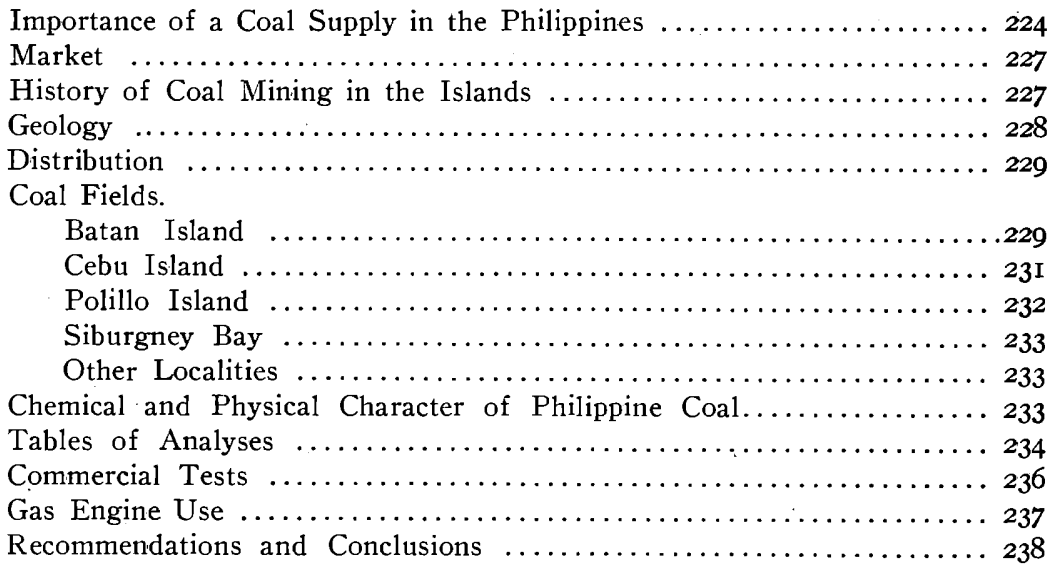

\section{INTRODUCTION.}

The importance of coal as a factor in the industrial advance of a country is of course unquestioned. It should take first rank. This has been called an Iron Age; rather should it be styled the Great Coal Age.

In the Philippines, especially, a supply of good coal is particularly necessary for several reasons, of which the most important are:

I. For steaming purposes, for stationary locomotion and marine engines, but chiefly for the last. Upon it depends the development of inter-island commerce.

2. For furnishing coke to be used in smelting processes.

3. Least important of all, as a heat producer. Except in the

${ }^{1}$ Chief of the Division of Mines, Bureau of Science, Manila. 


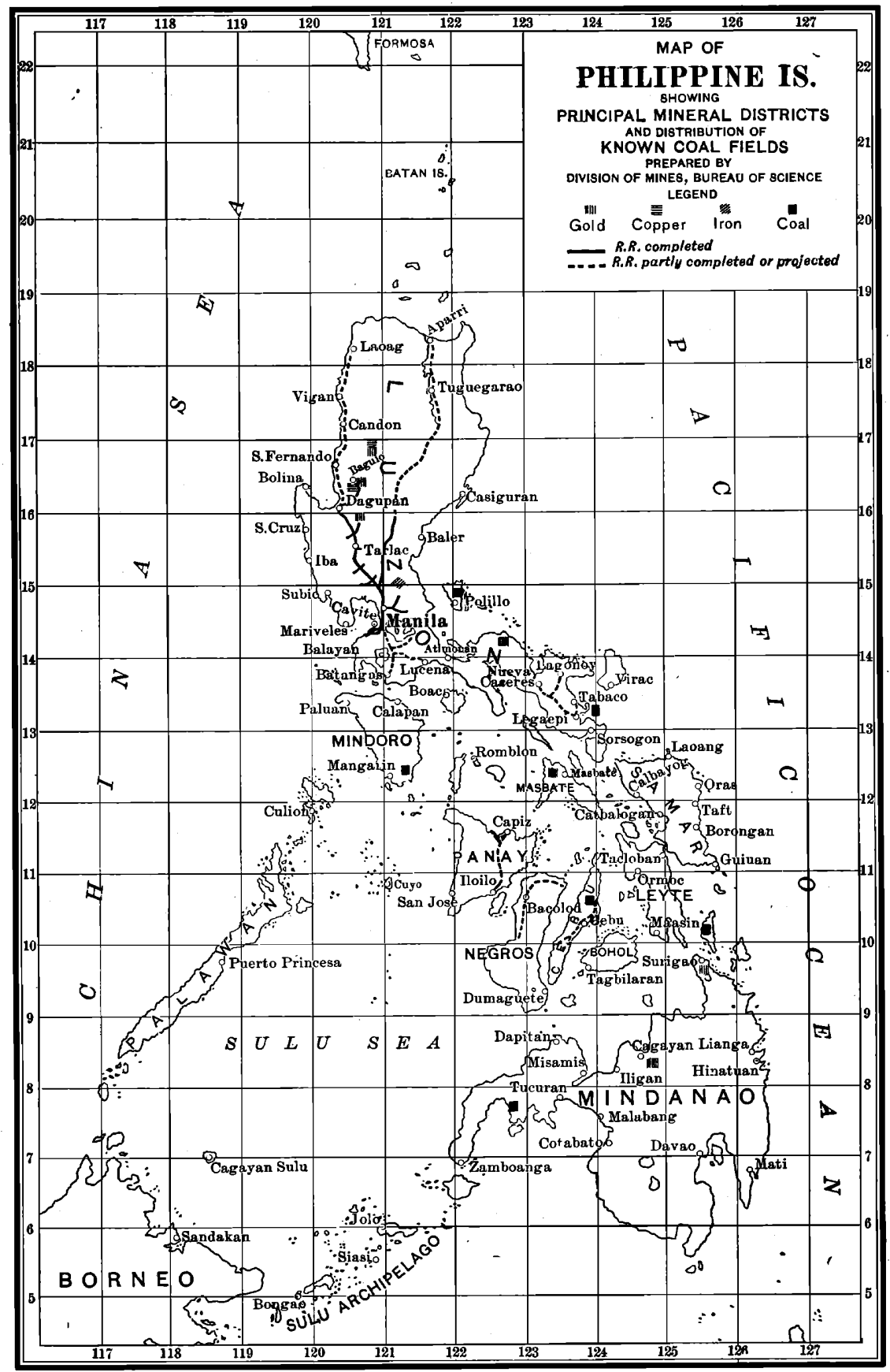

FIG. 34. Map of Philippine Islands showing distribution of the known coal fields. 
Highlands of Luzon and Mindanao it will never be needed for this purpose, and in these regions there is an abundance of wood, enough to last a considerable time.

In the matter of steaming, the chief demands for a good fuel arise, as said above, from the numerous inter-island trading vessels; second, from the railroads, third, from the United States Navy; from the United States Army for its transport service; and last from the various, and at present extremely limited, users of stationary engines in Manila, Cebu, Iloilo, and like towns. These consumers are named in the order of importance in time of peace. In the event of a war in the far East, it would be more or less reversed.

Practically all the coal used in the islands up to last year came from Japan and Australia, consumers having to pay exceptionally high prices due largely to great distance and duty. The price paid has ranged all the way from $\$ 7$ to $\$$ IO, or even more per ton, for what in many cases is exceedingly poor coal.

Within the past year, however, a beginning has been made in the production from Philippine mines and one operator has constantly supplied coal for about twenty-two small vessels per month. This coal comes from a property on the eastern end of Batan Island, which is a very small island off the southeast coast of Luzon.

In $1903^{1}$ the following amount was used in the Philippines. The table also gives the sources:

TABLE I.

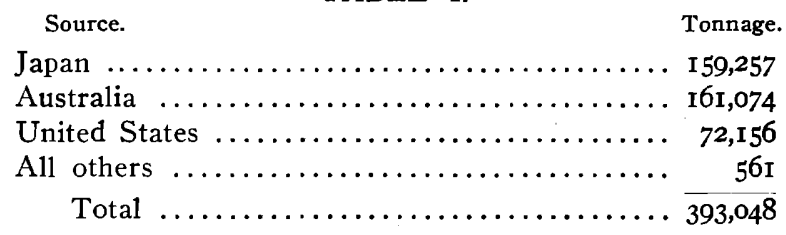

Taking the average cost per ton at the low figure of $\$ 7$, we have $\$ 2,75 \mathrm{I}, 336$ leaving the island and being circulated on the

\footnotetext{
${ }^{1}$ These figures, which were compiled by Mr. O. Halvorem Reinbolt, are somewhat old, but this is written in London and later figures are not at hand. The present condition is not essentially different.
} 
outside. That much for the year 1903 , it should be much greater now. Economists could easily point out what it means to have money continually leaving the country like this. Probably the army and navy do not spend as much now as formerly when more active operations were in progress, but on the other hand the demand for coal for other purposes has greatly increased within the last few years, and with the completion of the extensive new railroad lines, now building in several provinces, these figures should be doubled immediately.

Not only from an economic standpoint is it important that coal shall be obtained from the islands themselves, but the need of a coaling station for the United States in those far away islands is imperative. This is a matter quite apart from whatever may be their ultimate disposition, politically.

Furthermore, there exist what there is good reason to believe are extensive deposits of iron ore, which cannot be handled satisfactorily without a good supply of coke.

\section{HISTORY OF COAL MINING.}

The history of coal mining in these Islands dates from the year 1842, when the Spanish governor of Albay Province, one Velarde, worked and shipped coal from the vicinity of Calanaga Bay, Batan Island. The first discovery of coal by the Spaniards, $i$. $e$., the first to be recorded, was as early as I827, on the island of Cebu. Not much serious work was accomplished until 1890. At that time active operations were begun on both Batan and Cebu, but as the Senior Inspector of Mines, at that time Enrique Abella y Casariego, says, with poor results. The engineering was crude and the management of business details even worse. Too much money was spent on the plant before exploration had justified it. It think I am safe in saying that not a single mining venture in Spanish times proved other than a financial failure.

In 1896 Insurrectos broke out and in 1898 came the American occupation, and then followed several years of desultory disturbances which made it entirely out of the question to resume any industrial undertakings outside of the coast towns. Many 
of the prospectors and small mining concerns which did venture out into the hills came to grief, either having to suspend or the workers were killed while at work. There are many heroic but sad incidents belonging to this chapter of the history, but I shall forbear to open again those wounds which ought to be allowed to heal. My predecessor, Mr. H. D. McCaskey, who gave six years of hard service to the cause of mining in these islands, has elsewhere paid glowing tribute to those hardy pioneers who have now gone from us, following a longer trail.

In 1903 the United States Army began exploration on the western end of Batan, with the work in charge of Capt. $\mathrm{H}$. L. Wigmore, Corps of Engineers. In 1907 private concerns began exploration on and near the old Compostela properties in Cebu. Besides the government work another property has been opened up on the eastern end of Batan and it is from this that practically all the Philippine coal now comes. A definite start

- has been made again on Cebu, but up to the time of the writer's departure from the islands (May I5, I908) only development work had been accomplished.

Exploration and feeble attempts at mining have from time to time been made in Mindoro, Samar, Negros and Mindanao.

Coal occurs on most of the islands, both large and small, of the group. The accompanying. map (Fig. 34) gives the principal localities and the completed and projected railroads.

\section{GEOLOGY.}

The geology of the Philippine coal fields may best be outlined by giving the stratigraphic column as it has been worked out in Cebu. This, it must be understood, is subject to future modification in part, as little more than reconnaissance work has been done anywhere in the archipelago.

The geologic structure of the Philippine Islands is such as to introduce many difficulties into the profitable exploitation of the coal fields, yet these difficulties are not insuperable. Everywhere the strata are folded and faulted, and in many places shattered by earthquakes. Landslides are of frequent occurrence, because of steep slopes and excessive rainfall. The roof 
of the seams is scarcely ever found firm enough to stand without timbering. The geology is quite similar in many respects to that of the neighboring islands of Formosa, Borneo, Java and Japan.

\section{TABLE II.}

Stratigraphic Column of Compostela-Danao Coal Field.

Recent.

Miocene.

Alluvial deposits in streams and extensive and thick talus on all slopes; travertine.

Unconformity.

Oligocene?

Upper white limestone, coralline and containing Orbitoides, Lithothamnium, and many mollusca in its basal portion.

Shaly limestone and marl-cream colored and soft-unfossiliferous save in the lower marly portion.

Unconformity.

Extrusive rocks-chiefly andesite.

Terrestrial or Piedmont deposits consisting largely of conglomerate much oxidized.

Eocene?

Unconformity?

Coarse gray sandstone.

Coal measure shales with five (5) seams.

Unconformity.

Basal Diorite and conglomerate.

The age of the deposits is either Eocene or early Miocene. The limestone immediately overlying the Coal Measures pretty generally contains fossils, and of the many forms two are well known and are characteristic "zone fossils." They are Lepidocyclina (Orbitoides) insulc. Natalis Chap., a foraminifer with a wide distribution in the Indo-Australian region, and Lithothamnium ramossissnium Reuss, an alga, also widely distributed. These two mark the Middle Miocene or are about equivalent to the Helvetian Tortonian stage in the European column.

\section{BATAN ISLAND.}

Batan Island is twelve miles, almost due east, from Legaspi, in the Province of Albay, which in turn is a part of the long irregular arm of southeastern Luzon. The Island is from twelve to fifteen miles long and five or six in width. It has an irregular 
coast line and is for its small size quite mountainous, one peak attaining an elevation of approximately 1,500 feet.

The formations are: an igneous base of diorite, some serpentinized intrusives, the remnants of an iron formation, coal measures, including shales, sandstone and coal seams and at least two horizons of limestone. The upper one is quite coralline. In fact a coralline limestone quite probably covered the entire island at an earlier time. The coal beds are inclined at various angles, often steep and in some cases vertical. At the points where they can be most easily reached from the seashore (and it would be out of the question to do much in the interior of this island) the beds unfortunately dip into the island, thus necessitating hoisting and pumping. There are at least two good seams of over five feet, and one or two more of uncertain thickness, which can be easily reached, almost at sea level.

The military branch of the federal government has reserved the western half of the island and is about as the writer has been given to understand (he has not visited the island since I905), ready to install a complete plant including expensive docks. Transports as large as the government sends out to the East will be able to come within a few feet of shore and load.

The old Minas de Batan properties on the eastern and northern portion of the island have, it is understood, been quite abandoned. For several years a Spanish company employing Japanese miners, who used rather crude and wasteful methods, operated these properties, but never amounted to very much.

In the vicinity of the Barrio of Batan the Batan Coal Company has started work in good shape and is taking out in the neighborhood of a hundred tons a day. The mine cars are run out on a tramway which follows a projection of the coral reef and at the end of this reef, where the water is quite deep and the holding good, the coal is loaded directly into the ships.

It is really too soon to say whether much trouble from gas and water will be experienced, though I am rather inclined to expect such. The coal is quite rich in volatile matter as can be seen by referring to the analyses given below. In places, also, the coal contains considerable resin and sulphur and frequently 
takes fire on the dumps. When the writer visited the old Catanaga and Bilbao properties, there was evidence of this and the Bilbao tunnels are said to have been abandoned because of spontaneous combustion in the workings. These points are mentioned in detail, not to present too discouraging an outlook, but lest investors or engineers enter the field with high expectations which experience with the facts will prove unfounded. The facts should be clearly understood before setting out for a country situated at such a distance.

Batan Island is well situated, being directly in the track of steamers coming from San Francisco by way of Guam, which is the most direct route to Manila. A coaling station here would save the army transports the long northward trip to Japan where they now go to coal. On the other hand, it is off the track of many of the inter-island trading vessels and large tramps touching at Cebu, Iloilo and Manila.

\section{CEBU.}

Cebu is a long, narrow, mountainous island with no large rivers, few bays and but little coastal plain, yet it supports a greater population in proportion to its size than any other island of the whole Philippine group.

Geologically, Cebu is much the same as Batan, with the addition of some crystalline schists, igneous flows, all of which may yet be found in Batan.

At least fifteen localities are known scattered from one end of the Island to the other where coal comes to the surface. Many of these are not favorably located and therefore need no further mention here. The chief localities to which most attention was paid by the Spaniards and is to-day by Americans and Englishmen are as follows:

Camansi-six miles west of Danao.

Mte. Licos-six miles west of Compostela.

Mte. Uling-five to six miles west of Naga.

Alpaco-three to four miles west of Naga.

All these are situated on the eastern side of the Cordillera Central, the first two some sixteen to twenty miles north of the 
city of Cebu (which lies about central on the east coast), and the last two twelve to fifteen miles south of the same city.

Here we find sandstone, shales and limestones in very much the same order as on Batan. However, the number and position of the coal seams can be determined much better, for three reasons: first, more exploratory work has been done in these fields; second, the country is much more open, quite denuded of trees, but there is an excessive growth of cogan grass (which can of course be burnt off); third, the country is more dissected and hence more and better sections can be obtained.

In the Cumajumayan Valley the writer has seen five different seams exposed, the thickest measuring no less than twelve feet, the smallest seam about two feet, though only a foot and a half of the last named is solid coal. Taking all the facts into consideration, it would not be surprising if the drills on Batan Island revealed the presence of five seams there also.

A great number of claims have been staked out in these fields, but actual operations have been begun only at Camansi and Mte. Licos (Insular Coal Co.). The tramway which existed in Spanish times has been put in order from the mines to the coast at Danao. Here the company intends either to transship to the railroad now running to Cebu, or possibly to build its own dock at Danao.

\section{POLILLO AND OTHER FIELDS.}

There are four localities which at one time or another have commanded some attention, but which will always, doubtless, occupy second place. They are Polillo, Bulalaceo, Dinagat Island and Siburgney Bay. The first I have mentioned as being due east of Manila, off the east coast of Luzon; the second is at the southern end of the island of Mindoro; the third, a small island just north of Surigao Province, Mindanao; and the last northeast of Zamboanga about one hundred miles.

In Polillo exploration has shown that there is apparently a considerable supply of coal. It is quite similar in many respects to the Batan coal. Its geographicad position, however, may be a factor militating against it in its competition with other fields.

At Bulalaceo conditions appear to be not essentially different 
from those on Batan, the geographical location is favorable, but there is no other interest there to make it worth while for the steamers to run in, an advantage which Cebu enjoys.

Dinagat Island is still more isolated. There is very little information, official or otherwise, regarding the locality.

Siburgney Bay, which I visited in the winter of I907-08, has not only a favorable location, as lighters can go up the Siay River (a distance of thirteen miles from the sea) to within a couple of hundred feet of where the shafts or drifts would in all probability be located, but also for outcrop coal it has a more prepossessing appearance than the coal in any of the districts. The beds are tilted, but not so much as in other localities and timber is very plentiful and close at hand. The country is still a wilderness, and it is not altogether safe for white men to live there except in some numbers. The immediate tribesmen (Subanos) are fairly quiet and friendly, but there is no telling when the Moro will happen along to disturb the peace.

These coal measures must continue on around the head of the: bay and down into the Zamboanga Peninsula where the prevailing rock is crystalline schist. The writer fully believes drilling at indicated points on this Peninsula will show a higher grade of coal, not improbably an anthracite, as a result of the great compression to which the strata in this region have been subjected.

CHEMICAL AND PHYSICAL PROPERTIES.

Abundant data are at hand to show pretty clearly the chemical and physical characteristics of the Philippine coals. In 1905 Capt. H. L. Wigmore, U. S. A., and the writer made both analyses and calorimetric tests and at Capt. Wigmore's instigation steaming tests were made in vessels of the army and navy. ${ }^{1}$ Since that time Dr. Alvan J. Cox, chemist, in the Bureau of Science, has made many and more thorough tests both on laboratory and commercial scales, so that one of his latest statments regarding the subject, to be found in greater detail in his papers in the Philippine Journal of Science is here quoted. He says:

The Philippine coal deposits resemble those of black lignite, but are

${ }^{1}$ See Bull. No. 5, Mining Bureau, P. I., 1905. 
superior to the ordinary lignite in every respect. It is rather the exception for these coals to have a brownish color and they seldom show a woody structure. In appearance they are usually black and shiny, much resembling bituminous coal, but generally have a slightly lower calorific value than the latter. On the other hand, they have a much higher calorific value than ordinary brown lignite. The name "subbituminous" best describes this coal since it conveys the most accurate idea of its nature and value. So far as is definitely known, all Philippine coals are non-coking. Although I have investigated coals from every available authentic source, not a single sample of coking coal has been found among them. A few samples from time to time have shown incipient coking and recently one said to be from near Cebu, Cebu, has been brought in which gives a coke having the appearance of being of good quality. This may be the beginning of a sufficient supply and perhaps in the deeper beds coking coal may be abundant. The importance of such a discovery will at once be recognized when it is remembered that both iron and copper occur in the Philippines. I have tried to make coke from the incipient coking coal by variously treating it with heavy hydrocarbon compounds, but without success.

The quality of the Philippine coal will be shown by the following representative analyses:

TABLE III.

Representative Analyses of Philippine Coal. ${ }^{1}$

[Figures give percentages.]

\begin{tabular}{|c|c|c|c|c|c|}
\hline Source. & Moisture. & $\begin{array}{c}\text { Volatile } \\
\text { Combustible } \\
\text { Matter. }\end{array}$ & $\begin{array}{c}\text { Fixed } \\
\text { Carbon. }\end{array}$ & Ash. & Sulphur. \\
\hline \multicolumn{6}{|l|}{ Batan Island : } \\
\hline Bett's ... & $15.4 \mathrm{I}$ & 39.46 & $4 \mathrm{I} . \mathrm{OI}$ & 4.12 & 0.22 \\
\hline Military reservation......... & $7 \cdot 44$ & 35.26 & $44.8 \mathrm{I}$ & 2.49 & 0.25 \\
\hline \multicolumn{6}{|l|}{ Cebu : } \\
\hline Near Carmen .. & I6.70 & 35.10 & $43 \cdot 92$ & 4.28 & 0.67 \\
\hline 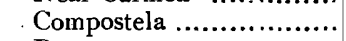 & 8.60 & 36.95 & 51.75 & 2.70 & 0.71 \\
\hline Danao ...................... & $9 \cdot 97$ & 37.94 & 46.29 & 5.80 & 0.8 \\
\hline 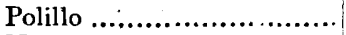 & 5.90 & 39.29 & 48.82 & 6.00 & \\
\hline Negros........................ & 15.90 & 35.44 & $34 \cdot 37$ & I 4.29 & 0.99 \\
\hline 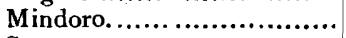 & I 5.35 & 46.26 & 32.24 & 6.15 & \\
\hline Samar....................... & 15.24 & $45 \cdot 3^{8}$ & 36.36 & 3.02 & \\
\hline
\end{tabular}

How best to utilize the coal deposits of this country is a question which has long attracted attention; however, but little progress has been made

${ }^{1}$ These analyses were made by the "smoking-off method." (Phil. J. Sc., Sec. A. Gen. Sci., I907, 2, 4I.) The empirical methods usually employed for the analyses of coals are not applicable to those of the Philippines, owing to certain peculiarities of the latter. The analyses as carried on by the "official method" ( $J$. Am. Chem. Soc., I899, 21, III6) indicate Philippine coal to be of a much poorer quality than is actually the case. 
toward its solution. I am at present carrying on some actual steaming tests under the boiler with as many coals as are available from representative sources. These, although not in all cases wholly satisfactory, are encouraging. They were all compared with Australian coal purchased by the Bureau of Supply on Circular Proposal No. 248, and used as a fuel by this Bureau. This coal is "double screened and picked twice." The contract price delivered at Manila, piled in the coal sheds and yards of the Civil Government is \$10.75 per ton of 2,240 pounds.

In considering the accompanying data it must be remembered that the samples of Philippine coal were used as they came from the mine and were neither screened nor picked.

TABLE IV.

Steaming Tests of Philippine Compared with Australian Coal as Unity.

[Figures give percentages.]

\begin{tabular}{l|c|c|c}
\hline \hline & $\begin{array}{c}\text { Outcrop } \\
\text { Coal from } \\
\text { Batan } \\
\text { Island. }\end{array}$ & $\begin{array}{c}\text { Coal Field } \\
\text { of Danao, } \\
\text { Cebu. }\end{array}$ & $\begin{array}{c}\text { Military } \\
\text { Reservation, } \\
\text { Batan } \\
\text { Island. }\end{array}$ \\
\hline Theoretical heat value as determined in the calorimeter... & 69 & 91 & 63 \\
Actual steaming value when burned under the boiler..... & 63 & 84 & $65 \frac{1}{2}$ \\
Efficiency from the standpoint of the actual heat value... & 91 & 92 & $77 \frac{1}{2}$ \\
\hline
\end{tabular}

- The loss of heat in the use of the Philippine coal was for the greater part through the smokestack, although a certain amount was due to fine coal falling through the grate. ${ }^{1} \quad$ The following data will show these facts:

Barring diluents, water, ash and sulphur, it is surprising what a general uniformity there is in all Philippine coal and this fact suggests,

TABLE V.

Flue Temperature when Various Coals were Burned.

[Degrees centigrade.]

\begin{tabular}{|c|c|c|c|c|}
\hline & $\begin{array}{l}\text { Australian } \\
\text { Coal. }\end{array}$ & $\begin{array}{l}\text { Batan Island } \\
\text { Coal. }\end{array}$ & $\begin{array}{c}\text { Danao, Cebu } \\
\text { Coal. }\end{array}$ & $\begin{array}{l}\text { Military } \\
\text { Reservation, } \\
\text { Batan Island } \\
\quad \text { Coal. }\end{array}$ \\
\hline 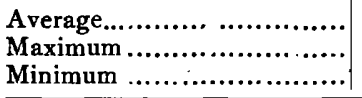 & $\begin{array}{l}360 \\
435 \\
330\end{array}$ & $\begin{array}{l}440 \\
504 \\
400\end{array}$ & $\begin{array}{l}389 \\
454 \\
391\end{array}$ & $\begin{array}{l}413 \\
468 \\
385\end{array}$ \\
\hline
\end{tabular}

${ }^{1}$ There is an exception in the case of the sample from the military reservation, Batan Island. This sample had evidently lain in the tunnel since the shutting down of the mine a few years ago and was thoroughly silted over, whereby the normal ash content of the coal was certainly increased six or seven per cent. It clinkered badly and required much working to keep the grate free.

There was a consequent loss of heat. 
if no other reason were apparent, that it was all bedded under about the same conditions.

TABLE VI.

Relative Loss of Combustible Matter in Ash.

\begin{tabular}{|c|c|c|c|c|}
\hline & $\begin{array}{c}\text { Australian } \\
\text { Coal. }\end{array}$ & $\begin{array}{l}\text { Batan } \\
\text { Island } \\
\text { Coal. }\end{array}$ & $\begin{array}{l}\text { Danao, } \\
\text { Cebu } \\
\text { Coal. }\end{array}$ & $\begin{array}{c}\text { Military } \\
\text { Reservation, } \\
\text { Batan Island } \\
\text { Coal. }\end{array}$ \\
\hline $\begin{array}{l}\text { Percentage of total refuse } \\
\text { Percentage of combustible matter in total refuse.... } \\
\text { Percentage of combustible matter of coal lost...... }\end{array}$ & $\begin{array}{r}13 \cdot 3 \\
22.32 \\
2.97\end{array}$ & $4 \cdot 5^{1}$ & $\begin{array}{r}6.1 \\
28.9 \\
1.0\end{array}$ & $\begin{array}{l}18.8 \\
36.5 \\
6.88\end{array}$ \\
\hline
\end{tabular}

It has several times been reported to me that Philippine coal burns exceedingly well when mixed with a certain proportion, say $3^{\circ}$ per cent., of Australian coal or even slack. This condition would be anticipated. The effect is probably entirely physical. The Australian, which is a coking coal, would help to sinter together and retard the escape of the light particles of the noncoking native coal, until combustion could be effected in the range of the water heating surface of an ordinarily constructed boiler.

The comparison of the theoretical and the actual ratios in Table IV is very satisfactory when all the facts are considered. The fuel was all fired in the gridiron-grate furnace of this Bureau, for which the usual fuel is Australian coking coal; in fact it is especially suited to and designed for the consumption of coal of this class. It is probable that a more satisfactory grate could be used for native coal and I am convinced that a saving would follow by the use of a different style of furnace. Without doubt much can be done in furnace construction by securing the proper firebox and grate to insure more complete combustion of the coal and more perfect abstraction of the heat from the hot gases. A furnace with a short firebox, planned for a high-grade steaming coal which burns with a short, hot, smokeless flame, is entirely unsuited to Philippine coal. The firebox must be greatly lengthened, or else a considerable portion of the fuel value of the volatile combustible matter, which approaches 50 per cent., will be lost.

It is worthy of mention that few of the Philippine coals form clinker, generally they are easily fired and burn well. This was the characteristic tenor of the reports of the officers in charge of the United States Army transports Chukong, Sacramento and Palawan ${ }^{2}$ when trials were made of the coal from Batan Island.

Granting the usefulness of Philippine coal for steaming purposes, there are other points to consider, namely, the economy and the preser-

${ }^{1}$ Estimated.

${ }^{2}$ Bull. Min. Bur., Manila, 1906, 5, 47 et seq. 
vation of the supply. In developing, opening up and working the mines there is always a large amount of outcrop coal and slack that is unsuited for steaming purposes and which for sake of economy should be used. Recently experiments with a producer gas plant ${ }^{1}$ have given unusually promising results. It was at first thought impossible to use poor coals in a gas producer to develop gas for a gas engine, but lignites worked well and the gas had as high a calorific value as that from any other coal which was used.

Mr. M. R. Campbell, ${ }^{2}$ a member of the committee in charge of the producer experiment says: "In every case the power produced by one pound of coal in the producer is many times the power produced by the same amount of coal in the steam plant. The ratios of these results run from I.96 to 3.34 ; that is, the very best West Virginia coal yielded practically three and one third times the amount of power when used in the producer that it did in the steam plant, and the very poorest coal yielded in the producer practically double the amount of power that it did in the steam plant."

The committee in charge remark ${ }^{3}$ that a simple engine was used in making the boiler tests. The efficiency of these tests might have been increased by substituting a compound engine; but the fact must not be overlooked that there is even a greater chance of increasing the efficiency by improving the gas engine, which is still new and unperfected.

The gas-producing power of the Philippine coals ${ }^{4}$ has been studied and while not always equal to that of American bituminous coal in quantity, the quality is in most cases fairly good. It probably would not be profitable to use these coals in the production of illuminating gas, for usually the most important factor in this process is the by-product, coke.

The report of the coal-testing plant of the United State Geological Survey at the Louisiana Purchase Exposition, St. Louis, Mo., 1904, gives a very pleasing outlook to the possibilities of producer-gas operations and there is probably no doubt but that Philippine coals are most admirably adapted to use in a producer plant. Physically they are ideal to handle. They are noncoking, they do not swell, they burn steadily, form very little clinker, and the ash would easily be removed automatically. Since the quantity of ash in a producer plant is of no material consequence, it seems likely that dirty coal could be used in this way to great advantage. It is also probable that the outcrop coal and slack employed in a producer-gas plant may become as valuable as the best grades of coal used in a steam plant, or perhaps even succeed the steam plant altogether for stationary work.

${ }^{1}$ U. S. G. S., P. P. 48, I906, 3.

${ }^{2}$ Econ. GEoL., 1907, 2, 287.

${ }^{8}$ U. S. G. S., P.P. 48, 1906, 3, I324.

‘Phil. J. Sc., I906, I, 877. 
With a satisfactory scheme for the utilization of the upper and poorer grade of coal, the mines can successfully be operated and the deeper coal can be used for steaming, where a producer gas plant and gas engine are impracticable. For the production of power, the utilization of our lowgrade and outcrop coal for producer gas seems extremely promising.

This bureau hopes to establish a trial plant at no distant date and when it is in operation we can add very definite data to our present information. It is hoped that such a plant can compete with the best steam plant and especially that it can burn successfully the slack and waste products which are not utilizable for steaming purposes.

\section{CONCLUSION.}

In conclusion we might sum up the unfavorable and the favorable features connected with the subject of coal in the Philippines. The less favorable features are:

I. Somewhat broken condition of the strata.

2. Weak roof and floor.

3. Inferior grade of the coal (so far as known).

4. The inferior quality of labor, almost totally unskilled and not always thoroughly reliable, due to inherent Malay characteristics.

5. Difficulties attending exploratory work, jungle, lack of roads, etc.

The more favorable features are:

I. An exceptionally good market.

2. Cheapness of the labor.

3. Abundance of timber.

4. Distance from possible competitors.

Whether these last named can offset the first is only to be ascertained by actual trial. The writer believes they can and that coal mining may be carried on at a profit; in fact, this is being done in one instance.

It must be said that the present mining laws are not as favorable to capital as they might be. A remedial bill is now before the Congress of the United States, and it is to be sincerely hoped that it may become a law. Certainly the government should recognize the importance of making some concessions in order that capital will be encouraged to come in and develop this most important resource. 